\title{
PROSES DAN TEKNIK SUPERVISI
}

\author{
Nofita Sari \\ E-mail
}

nofitasari91199@gmail.com

Universitas Negeri Padang

\begin{abstract}
ABSTRAK
proses dan teknik supervisi merupakan kegiatan yang mengacu pada permasalahan yang dihadapi serta meningkatkan mutu pendidikan. ada beberapa proses supervisi diantaranya: perencanaan, pelaksanaan, evaluasi, teknik supervisi merupakan cara-cara dalam mencapai tujuan tertentu, dengan supervisi pendidikan sangat penting untuk diterapkan dalam lembaga pendidikan.
\end{abstract}

kata kunci: proses, teknik supervisi

\section{PENDAHULUAN}

Proses supervisi merupakan serangkaian kegiatan yang dilakukan dalam supervisi pendidikan. Proses ini sangat penting dalam melihat sejauh mana keberhasilan belajar mengajar. Teknik supervisi merupakan cara-cara yang ditempuh dalam mencapai tujuan tertentu, baik dalam hubungan penyelesaian masalah guru-guru dalam mengajar. Mengembangkan kelembagaan masalah-masalah lain serta dapat menigkatkan mutu pendidikan.

Proses dan teknik supervisi pendidikan perlu dan penting untuk di terapkan secara baik dan benar dalam suatu lembaga pendidikan.

Karena kedua hal tersebut nantinya menyangkut tentang kualitas sekolah.

\section{A. PROSES SUPERVISI}

Proses supervisi merupakan rangkaian kegiatan yang dilaksanakan ketikan melakukan supervisi. Menurut tim pakar manajemen pendidikan (2004:53) secara umum proses pelaksanaan supervisi dilaksanakan melalui tiga tahap yaitu:

1. Perencanaan

Kegiatan perencanaan mengacu pada kegiatan identifikasi permasalahan. Lengkah-langkah yang dilaksanakan dalam perencanaan supervisi adalah:

a. Mengumpulkan data melalui kunjungan kelas, pertemuan pribadi atau rapat staf. 
b. Mengelola data dengan melalukan koreksi kebenaran terhadap data yang dikumpulkan.

c. Mengklasifikasi data sesuai dengan bidang permasalahan

d. Menarik kesimpulan tentang permasalahan sasaran sesuai dengan keadaan yang sebenarnya.

e. Menetapkan teknik yang tepat digunakan untuk memperbaiki atau meningkatkan profesionalisme pendidik.

2. pelaksanaan

Kegiatan pelaksanaan merupakan kegiatan nyata yang dilakaukan untuk memperbaiki atau meningkatkan kemampuan pendidik.kegiatan pelaksanaan merupakan kegiatan bantuan dari supervisor kepada pendidik, agar dapat terlaksana dengan efekif, pelaksanaannya harus sesuai dengan perencanaan yang telah ditetapkan dan ada follow up untuk melihat keberhasilan proses dan hasil pelaksanaan supervisi.

3. Evaluasi

\begin{tabular}{|c|c|}
\hline Kegiatan & evaluasi merupakan \\
\hline kegiatan & menelaah \\
\hline keberhasilan & proses dan \\
\hline pelaksanaan & supervisi. \\
\hline dilaksanakan & secara komprehensif. \\
\hline Sasaran & evaluasi \\
\hline
\end{tabular}

terlibat dalam proses pelaksanaan supervisi.

Hasil dari supervisi akan dijadikan pedoman untuk menyusun program perencanaan berikutnya. Soetopo dan soemanto (1984:84-85) mengemukakan evaluasi berpedoman pada tujuan yang telah ditetapkan dan tujuan supervisi drumuskan sesuai dengan corak dan tujuan sekolah.

Proses pelaksanaan supervisi menempuh tiga tahapan, yaitu petemuan pendahuluan, observasi pendidik yang sedang mengajar, dan pertemuan balikan (burhanuddin dkk, 2007:36

B. TEKNIK SUPERVISI

(piet A. Sahertian dan frans mataheru, 198245 dst.) menjelaskan teknik-teknik supervisi pendidikan tersebut:

1. teknik supervisi yang bersifat individual. Teknik indivdual dipergunakan apabila orang yang disupervisi dihadapi secara perorangan biasanya dilakukan terhadap individu-individu yang mempunyai masalah khusus dan bersifat pribadi.

Teknik supervisi yang bersifat individu ini dapat dijelaskan atas beberapa macam, yakni:

a. kunjungan kelas 
untuk mengetahui lebih dekat tentang belajar mengajar guru di kelas, seorang kepala sekolah, pemilik pengawas biasanya mengadaka kunjngan pada setiap kelas dimana guru-guru sedang mengajar.tujuannya untuk menolong guru-guru memecahka kesulitan yang mereka hadapi dan mempelajari sifat dan kualitas cara belajar anak serta bagaimana membimbing anak murid tersebut.

a. Teknik (individu dan kelompok, langsung dan tidak langsung)

Dalam supervisi dikenal dengan dua teknik besar, yakni teknik individu dan teknik kelompok. Teknik individual antara laian berupa 1.) kunjungan dan observasi kelas 2). Individual conference 3). Kunjungan antar guru-guru 4).evaluasi diri 5). Supervisory buletn 6). Profesional reading7). Profesional writing

Sedangkan teknik kelompok

1). Field trips 2).orientasi guru baru 3). Curriculum laboratory 4). Panitia

5). Perpustakaan profesioanal

6). Demostrasi mengajar

7). Lokakarya 8). Field trips for staff personnels 9). Pannel or forum discussion 10). In service trainning dan 11).

Organisasi profesional.

Teknik supervisi langsung adalah teknik yang digunakan untuk menyampaikan harapan supervisor kepada guru dengan jelas. Supervisor dapat menggunakan bahasa langsung dan penguatan. Rifa'i (1987) mengemukakan bahwa teknik langsung dalam supevisi yaitu: cara berkomunikasi dengan berhubungan langsung antara supervisor dengan guru melaluui kunjungan kelas, pertemuan pribadi, rapat staf dan lokakarya.

Daftar pustaka

Supandi. 2013. Administrasi dan supervisi pendidikan. Jakarta: Departemen Agama Universitas Terbuka.

Rifai, M. Moh. 1987. Supervisi pendidikan. Bandung: Jemmars 